\title{
Degree of Phosphorous Saturation in Intensively Cultivated Soils in Sri Lanka
}

\author{
E.A.G.S. Amarawansha and S.P. Indraratne ${ }^{1^{*}}$ \\ Postgraduate Institute of Agriculture \\ University of Peradeniya \\ Sri Lanka
}

\begin{abstract}
The loss of Phosphorous (P) from intensively cultivated soil is one of the major causes of reducing water quality. The Degree of Phosphorous Saturation (DPS) which relates the extractable $P$ of a soil to its $P$ adsorption capacity is a good indicator of the soils potential to release P. Therefore, the objective of this research was to determine the DPS in intensively cultivated soils in Nuwara Eliya region of Sri Lanka and to predict P losses with runoff water. Twenty seven surface soil samples from intensively cultivated fields were analyzed for $p H$, water extractable $P\left(P_{H 20}\right)$ and Mehlich 3 extractable $P$. Single point adsorption study was conducted to determine the $P$ adsorption capacity of soil $\left(P_{150}\right)$. The Degree of Phosphorous Saturation was calculated as the percentage ratio between Mehlich3 extractable $P$ and single point adsorption capacity. The runoff potential of $P$ from soils was evaluated using $P_{\mathrm{H} 20}$, where $20 \%$ DPS was considered as the cutoff point for runoff losses. The studied soils were acidic to strongly acidic in reaction. Very high Mehlich -3 extractable P levels ranging from 17.3 to $298.4 \mathrm{mg} / \mathrm{kg} P$ with the mean of $155.5 \mathrm{mg} / \mathrm{kg} P$ were observed. Phosphorous adsorption capacities were also high in soils with a mean of $664.7 \mathrm{mg} / \mathrm{kg}$ P. Calculated DPS values ranged from 1.7 to $80.4 \%$ with mean of $27.7 \%$, while, $55.6 \%$ of soils had DPS values higher than 20\%. DPS showed a considerably strong relationship $\left(r^{2}=0.67\right)$ with $P_{H 20}$ and the corresponding $P_{H 20}$ at $20 \%$ DPS was $8.8 \mathrm{mg} / \mathrm{kg} P$. Along with high DPS values, $59.3 \%$ of the studied soils were observed to exceed critical $P_{H 20}$ content and thereby they were at a risk of losing $P$ from soil due to runoff.
\end{abstract}

Key words: Degree of Phosphorous Saturation (DPS), Mehlich 3 extractable P, Water extractable $P\left(P_{H 20}\right)$.

\section{INTRODUCTION}

Phosphorus is an essential plant nutrient which leads to optimum crop growth and production (He et al., 2004). It is less water soluble and thus the by availability for plants is very low, seldom exceeding about $0.01 \%$ of the total P in the soil (Brady and Ray, 1996). Therefore, the fertilization with $\mathrm{P}$ is necessary to achieve optimum level of crop production (Allen and Mallarino, 2006).

Long term continuous application of $\mathrm{P}$ fertilizers and other $\mathrm{P}$ sources, such as organic wastes and manure cause $\mathrm{P}$ accumulation in surface horizon due to low crop use efficiency $(<25 \%)$. Fertilizer addition without considering crop removal may also cause excess $\mathrm{P}$ in soil (Zhang, et al., 2004). It is reported that, the majority of Sri Lankan farmers apply higher than recommended quantity of fertilizer (National Science Foundation, 2000) aiming for higher economical benefits. Therefore, in agricultural soils when high quantities of $\mathrm{P}$ are received, available $\mathrm{P}$ content exceeds the critical $\mathrm{P}$ for fertilizer response (Saavendra, et al., 2006). In

1* To whom correspondence should be addressed: srimathii@pdn.ac.lk

Department of Soil Science, Faculty of Agriculture, University of Peradeniya, Peradeniya, Sri Lanka 
this situation, soil $\mathrm{P}$ has become more of an environmental concern than an agronomic one in areas with intensive cropping and livestock production (Central Environment Authority, 1995; Sharpley et al., 1995).

The Degree of phosphorus saturation (DPS) is an environmental index to assess the potential of soil for the release of $P$ to runoff and leaching (Allen and Mallarino, 2006). DPS provides a reliable and unifying criterion for making environmentally acceptable and agronomically efficient fertilizer P recommendations for sustaining crop production (Khiari et al., 2000). Therefore, the objective of this research was to determine the DPS in intensively cultivated soils in Sri Lanka and to predict P losses with runoff water.

\section{MATERIALS AND METHODS}

For this study, 27 representative surface soil samples were collected from some intensively cultivated vegetable fields from WU3 and WU2a agro-ecological zones in Nuwara Eliya district (Table 1). The samples were air dried, gently crushed and passed through a $2 \mathrm{~mm}$ sieve to remove coarse fragments and then stored in tightly sealed plastic bottles until analysis were conducted.

Table 1. pH (1:2.5 soil: $\mathrm{KCl})$, Mehlich- 3 extractable phosphorus $\left(\mathrm{P}_{\mathrm{M} 3}\right)$ values and adsorption capacity, $P_{150}$ values of studied soils

\begin{tabular}{lcccc}
\hline Location & Agro-ecological zone & $\mathbf{p H}$ & $\begin{array}{c}\mathbf{P}_{\mathbf{M} 3} \text { in soil } \\
(\mathbf{m g} / \mathbf{k g})\end{array}$ & $\begin{array}{c}\mathbf{P}_{\mathbf{1 5 0}} \\
(\mathbf{m g} / \mathbf{~ k g})\end{array}$ \\
\hline Sandathenna & WU3 & 5.2 & 207 & 608 \\
Palagolla & WU2a & 5.5 & 17 & 1005 \\
Sandathenna & WU3 & 5.0 & 219 & 572 \\
Sandathenna & WU3 & 3.9 & 260 & 654 \\
Sandathenna & WU3 & 4.9 & 232 & 437 \\
Kudaoya & WU3 & 5.9 & 77 & 681 \\
Kudaoya & WU2a & 5.2 & 230 & 617 \\
Labukele & WU2a & 5.5 & 298 & 371 \\
Kandapola & WU3 & 4.5 & 249 & 708 \\
Kanadapola & WU3 & 3.9 & 107 & 915 \\
Meepilimana & WU3 & 4.6 & 171 & 690 \\
Hawaeliya & WU3 & 5.8 & 111 & 500 \\
Seethaeliya & WU3 & 5.5 & 128 & 599 \\
Lalukele & WU3 & 5.2 & 88 & 635 \\
Magastota & WU3 & 5.8 & 227 & 185 \\
Sanadathenna & WU3 & 4.4 & 211 & 771 \\
Ruwaneliya & WU3 & 6.4 & 91 & 608 \\
Kalukele & WU3 & 5.8 & 63 & 1167 \\
Ruwaneliya & WU3 & 4.2 & 91 & 482 \\
Ruwaneliya & WU3 & 5.2 & 173 & 419 \\
Hawaeliya & WU3 & 5.7 & 206 & 500 \\
Topass & WU3 & 5.2 & 219 & 1041 \\
Meepilimana & WU3 & 5.1 & 34 & 509 \\
Meepilimana & WU3 & 5.5 & 124 & 753 \\
Magastota & WU3 & 4.2 & 116 & 906 \\
Kandapola & WU3 & 5.7 & 175 & 554 \\
Kandapola & WU3 & 4.4 & 76 & $\mathbf{1 8 5}$ \\
Minimum & & $\mathbf{1 1 6 7}$ \\
Maximum & & $\mathbf{3 . 9}$ & $\mathbf{1 7}$ & \\
Mean & & $\mathbf{6 . 4}$ & $\mathbf{2 9 8}$ & $\mathbf{1 5 1}$ \\
\hline
\end{tabular}


The soil $\mathrm{pH}$ was measured by the glass electrode $\mathrm{pH}$ meter using a soil to solution ratio of 1:2.5 in distilled water and in $0.1 \mathrm{M} \mathrm{KCl}$ solutions (Rowell, 1994). Water and Mehlich-3 extractable $\mathrm{P}\left(\mathrm{PM}_{3}\right)$ was determined by the Molibdate blue color method. For the determination of water extractable phosphorus $\left(\mathrm{P}_{\mathrm{H} 2 \mathrm{O}}\right), 20 \mathrm{~mL}$ of distilled water was added to 2 grams of soil $(<2 \mathrm{~mm})$ which was in a plastic bottle and shaken for 30 minutes in a reciprocal shaker. They were then filtered through Whatman no. 42 filter paper. The filtrate was used to measure the water extractable $\mathrm{P}$ (Kuo, 1996). Mehlich-3 extractable phosphorus $\left(\mathrm{P}_{\mathrm{M} 3}\right)$ was determined by equilibrating $25 \mathrm{~mL}$ of Mehlich-3 solution with $2.5 \mathrm{~g}$ of soil in a plastic vial (Mehlich, 1984). It was shaken for 5 minutes in a reciprocal shaker and then filtered through Whatman no 42 filter paper. Phosphorus concentration of the aliquot was measured by spectrophotomettrically at $680 \mathrm{~nm}$.

Single point adsorption study was conducted as described by Ige et al. (2005) using a $\mathrm{P}$ concentration of $150 \mathrm{mg} \mathrm{P} / \mathrm{L}$. Two grams of air dried, sieved soil was weighed into plastic vials and $20 \mathrm{~mL}$ of solution containing $150 \mathrm{mg} / \mathrm{L}$ in $0.001 \mathrm{M} \mathrm{KCl}$ was added. The suspension was placed in a shaker and shaken for $24 \mathrm{~h}$. at room temperature. The samples were filtered through Whatman number 1 filter paper and the remaining $\mathrm{P}$ of the filtrate was determined calorimetrically using molibdate blue method. The amount of $\mathrm{P}$ adsorbed, $\mathrm{P}_{150}$, was determined by the difference between the amount of $\mathrm{P}$ added to the soil and the equilibrium $\mathrm{P}$ solution concentration. Then, DPS was calculated using $\mathrm{P}_{150}$ as the denominator and Mehlich-3 extractable $\mathrm{P}$ as the numerator.

Relationships were developed between calculated DPS and water extractable P which is used as an index of $\mathrm{P}$ in runoff losses in this study. The runoff potential of $\mathrm{P}$ from soils was evaluated using $\left(\mathrm{P}_{\mathrm{H} 20}\right)$, where $20 \%$ DPS (Ige et al., 2005) was considered as the cutoff point for runoff losses.

\section{RESULTS AND DISCUSSION}

\section{General soil properties}

The studied soils of intensively cultivated fields of Nuwara Eliya area were acidic to strongly acidic in reaction; $\mathrm{pH}$ ranged from 3.9 to 6.4 with a mean of 5.1 (Fig. 1) by proving general $\mathrm{pH}$ values of the area (Withana and Kumaragamage, 1993). Acidic $\mathrm{pH}$ of the soils is a norm in up country wet zone due to heavy rainfall. The upward trend of $\mathrm{pH}$ in some soils may be due to application of liming materials and poultry manure to the fields.

Mehlich -3 extractable P was very high and ranged from 17 to $298 \mathrm{mg} / \mathrm{kg}$ with a mean of 156 $\mathrm{mg} / \mathrm{kg}$ (Table 1) indicating the availability of high extractable P (Sims et al., 2002). In general, the need of Olsen extractable P for optimum crop production is less than $30 \mathrm{mg} / \mathrm{kg}$ while it has been proved that some plants perform well under higher P contents $(48 \mathrm{mg} / \mathrm{kg}$ ) (Keerthisinghe et al., 2007) . Twenty five soils, out of 27 soils studied (92.6\%) showed exceeding $\mathrm{P}$ concentrations higher than $48 \mathrm{mg} / \mathrm{kg}$ which were extracted by Mehlich 3 solution (Table 1).

\section{Phosphorus sorption properties of soils}

The single point adsorption capacity, $\mathrm{P}_{150}$, of soils ranged 185 and $1167 \mathrm{mg} / \mathrm{kg}$ with a mean value of $665 \mathrm{mg} / \mathrm{kg}$ (Table 1) indicating the very high adsorption capacities of the studied 
soils. The lower the $\mathrm{pH}$, the more available are the metallic ions, especially $\mathrm{Mn}, \mathrm{Fe}$ and $\mathrm{Al}$ which subsequently combine with soluble P and form insoluble compounds (Soon, 1991).

\section{Calculation of degree of phosphorus saturation (DPS)}

The estimated adsorption capacity, $\mathrm{ES}_{\max }$ represents the actual capacity of soil to adsorb $\mathrm{P}$ while being a time consuming and costly procedure (Pautler and Sims, 2000). The single point adsorption capacity, $\mathrm{P}_{150}$ can be considered as an index representing the $\mathrm{P}$ retention capacity of soil due to its good correlation with $\mathrm{ES}_{\max }(\mathrm{p}<0.001)$ (Ige et al., 2005).

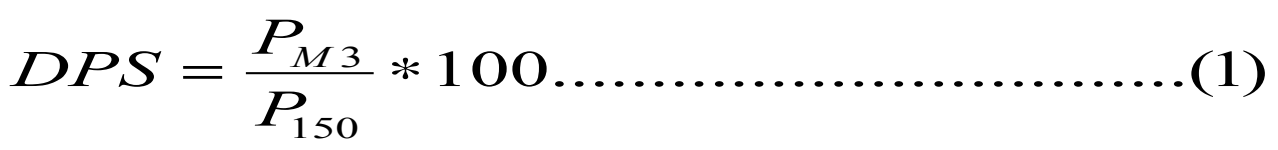

Calculated DPS values using above equation, ranged from 1.7 to $80.4 \%$ with mean of $27.7 \%$. Researchers have used 20\% DPS as cut off point for loss (Fig.1) of P due to runoff (Khiari et al., 2000; Sims et al., 2002 and Ige et al., 2005). Of the soils studied, 55.6\% showed higher DPS values than $20 \%$ indicating severe risk of P loss from soil to water, whereas the rest showed less potential for runoff $\mathrm{P}$ loss. These low values were due to the higher values obtained for adsorption capacity of these soils which confirm earlier studies reported for the area (Withana and Kumaragamage, 1993; Indraratne et al., 2009).

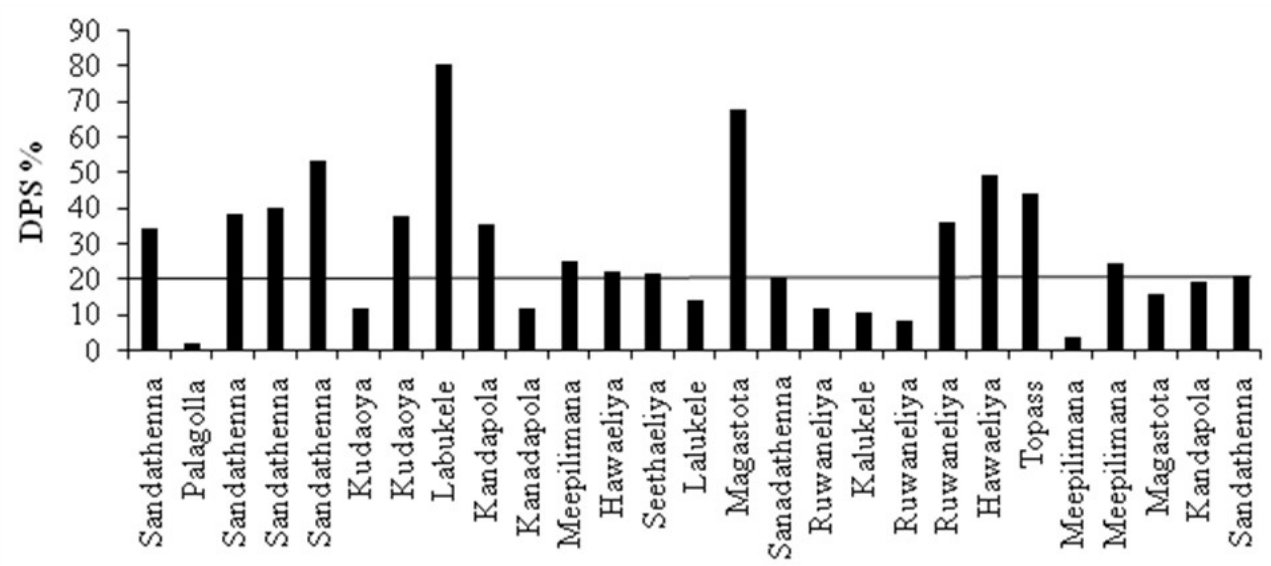

Fig. 1. Distribution of calculated DPS of studied soils

\section{Evaluation of the calculated degree of $P$ saturation}

Water extractable $\mathrm{P}\left(\mathrm{P}_{\mathrm{H} 2 \mathrm{O}}\right)$ was used as the index of soil $\mathrm{P}$ to evaluate runoff losses in many studies (Pote et al., 1996, Davis et al., 2005 and Ige et al., 2005). $\mathrm{P}_{\mathrm{H} 2 \mathrm{O}}$ of the studied soils were ranged between 0.93 and $58.74 \mathrm{mg} / \mathrm{kg}$ and the mean value was $14.63 \mathrm{mg} / \mathrm{kg}$. A strong relationship $\left(\mathrm{r}^{2}=0.677, \mathrm{p}=0.001(\mathrm{n}=27)\right)$ was observed between $\mathrm{P}_{\mathrm{H} 20}$ and calculated DPS (Fig. 2). At $20 \%$ DPS, the corresponding $\mathrm{P}_{\mathrm{H} 2 \mathrm{O}}$ was calculated as $8.8 \mathrm{mg} / \mathrm{kg}$ using the above relationship. Therefore, if $\mathrm{P}_{\mathrm{H} 2 \mathrm{O}}$ in a soil exceeds this threshold $\mathrm{P}$ concentration, it can be concluded as that soil has a high risk of runoff losses of P. Sixteen of twenty seven $(59.3 \%)$ soils studied have shown exceeding $\mathrm{P}_{\mathrm{H} 2 \mathrm{O}}$ levels having greater risk of $\mathrm{P}$ loss. 


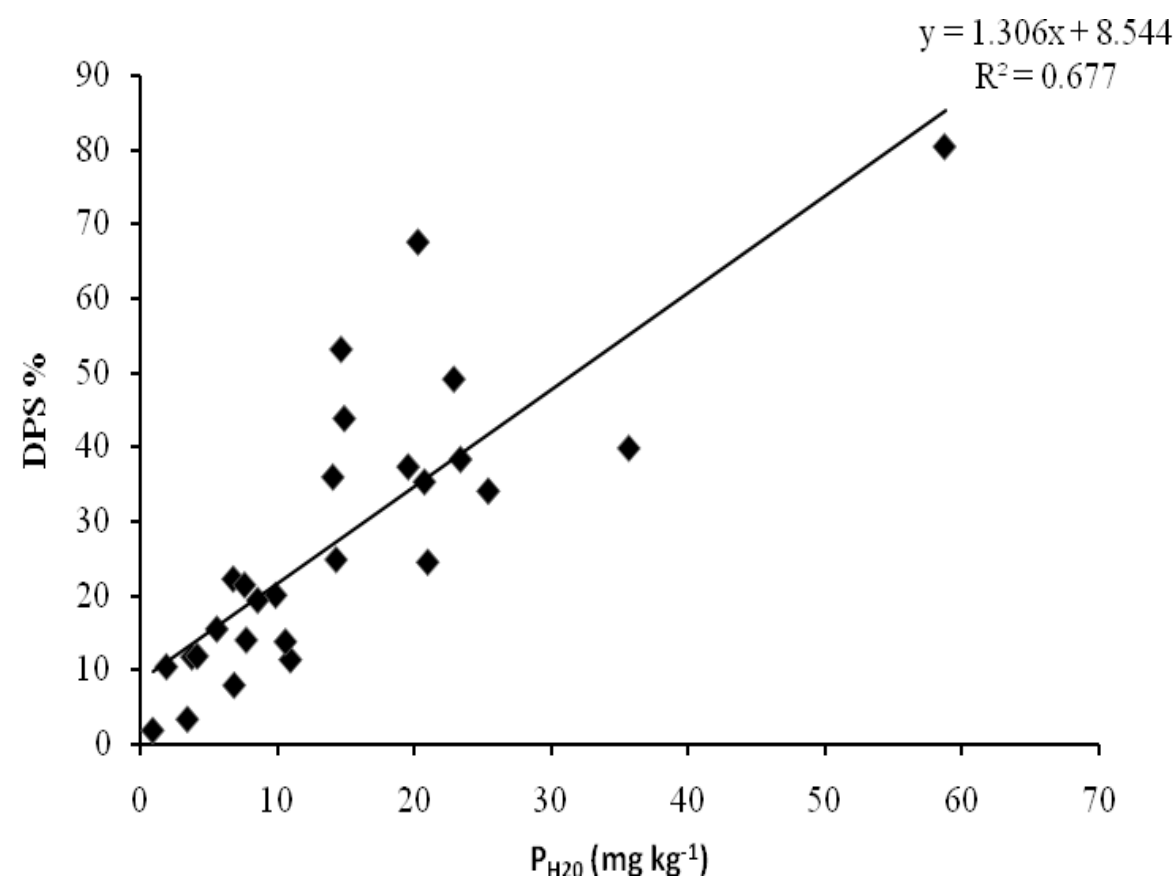

Fig. 2. Relationship between water extractable $P$ and calculated DPS

\section{CONCLUSION}

Intensively cultivated soils in Nuwara Eliya exhibit very high available P concentrations in surface layer posing negative impacts on water quality in the area. On the other hand, the soils also have considerably high $\mathrm{P}$ adsorption capacities. However, 55.6\% of studied soils showed higher DPS values than $20 \%$ indicating the risk of P loss from soil to water. Degree of Phosphorous Saturation calculating methods using Mehlich $3 \mathrm{P}$ as the numerator and $\mathrm{P}_{150}$ as denominator gave significant and positive relationship with water extractable $\mathrm{P}$. This study provides the preliminary $\mathrm{P}$ indexing for $\mathrm{P}$ runoff losses for intensively cultivated fields in Sri Lanka which requires field validations in future studies.

\section{ACKNOWLEDGEMENT}

Appreciation is expressed to Mr. U.W.S.P. Yapa, Research officer, Horticultural Crop Research and Development Institute, Gannoruwa (HORDI), and Mr. M.M.C.B. Ekanayake, Technical Officer, Department of Soil Science, Faculty of Agriculture, University of Peradeniya for his assistance. 


\section{REFERENCES}

Allen, B.L. and Mallarino, A.P. (2006). Relationship between extractable soil phosphorus and phosphorus saturation after long- term fertilizer and manure application. Soil Sci. Soc. of Am. 70, 454-463.

Brady, N.C. and Well, R.Ray. (1996). Phosphorus. pp. 445-486. In The nature and properties of soil. $11^{\text {th }}$ Ed. Prentice-Hall, Inc. A Simon and Schuster Company. Upper Saddle River, New Jersey, NY.

Central Environment Authority. (1995). Man and Environment (An Introduction to Environmental Studies). Central Environment Authority, Sri Lanka.

Davis, R.L., Zhang, H., Schroder, .J.L., Wang, J.J., Payton, M., and Zazulak, A. (2005). Soil characteristics and phosphorus level effect on phosphorus loss in runoff. J. Envt. Qual. 34, $1640-1650$.

He, Z., Griffin, T.S. and Honeycutt, W. (2004). Evaluation of soil phosphorus transformation by sequential fractionation and phosphatase hyrolysis. Soil science. 169, 515-527.

Ige,D.V., Akinremi, O. O and Flaten, D.N. (2005a). Environmental index for estimating the risk of phosphorus loss in calcareous soils of Manitoba. . J. Envt. Qual. 34, 1944-1951.

Indraratne, S.P., Sanjeewani, U.K.P.S. and Amarawansha, E.A.G.S. (2009). Soil properties on phosphorus sorption for some soils of Sri Lanka. J. of Nat. Agric. Sci. 49, 51-63.

Keerthisinghe, J.P., Kumaragamage, D., and Sultanbava, F. (2007). Evaluation of sitespecific fertilizer recommendation for cauliflower (Braccica oleracea L.) in locations in Sri Lanka. Tropical Agric. Res. 19, 229-239.

Khiari, L., Parent, L.E., Pellerin, A., Alimi, A.R.A., Tremblay, C., Simard, R.R and Fortin, J. (2000). An agri-environmental phosphorus saturation index for acid coarse- textured soils. J. Envt. Qual. 29,1561-1567.

Kuo, S. (1996). Phosphorous. 869-919. In: D.L. Sparks (Ed.). Methods of Soil Analysis; Part 3: Chemical methods. American Society of Agronomy, Soil Science Society of America, Madison,WI, USA.

Mehlich, A. (1984). Mehlich 3 soil test extractant: A modification of Mehlich 2 extractant. Commun. Soil Sci. Plant Anal. 15,1409-1416.

National Science Foundation. (2000). National Resources of Sri Lanka. 47/5, Maitland Place, Colombo 7, Sri Lanka.

Pautler, M. and Sims, J.T. (2000). Relationship between soil test phosphorus, soluble phosphorus, and phosphorus saturation In Delaware soils. J. Soil Sci. Soci. Am. 64, 765-773.

Pote, D.H., Daniel, T.C., Shapley, A.N., Moor, P.A., Edwards, D.R. and Nichols, D.J. (1996). Relating extractable soil phosphorus to phosphorus losses in runoff. J. Soil Sci. Soc. Am. 60, 855-859. 
Rowell, D.L. (1994). Soil Science: Methods and Applications. Longman Publishers Ltd., London, UK. 169.

Saavedra, C., Velasco, J., Pajuelo, P., Perera, F., and Delgado, A. (2006). Effect of tillage on phosphorus release potential in Spanish Vertisol. J. Soil Sci. Soci. Am. 71, 56-63.

Sharpley, A.N., Danial, T.C., Sims, J.T. and Pote, D.H. (1995). Determining environmentally sound soil phosphorous levels. J. Soil Water Conserv. 51, 160-166.

Sims, J.T., Maguire, R.O., Leytem, A.B., Gartley, K.L. and Pautler, M.C (2002). Evaluation of Mehlich 3 as an agri-environmental soil phosphorus test for the mid-Atlantic United States. Soil Sci. Soc. Am. 66(6),2016-2032.

Soon, Y.K. (1991). Solubility and retention of phosphorous in soils of North Western Canada Prairie. Candian. J. Soil Sci. 70 (2), 227-237.

Withana, A.K. and Kumaragamage, D. (1993). Retention of P by some surface soils of Sri Lanka. Tropical Agric. Res. 5, 60-68.

Zhang, T.O., MacKenzie, A.F., Liang, B.C. and Drury, C.F. (2004). Soil test phosphorus and phosphorus fractions with long-term phosphorus addition and depletion. Soil Sci. Soc. Am. $68,519-528$. 